\title{
Pastoral care and gays against the background of same-sex relationships in the Umwelt
}

of the New Testament

\author{
Yolanda Dreyer \\ Department of Practical Theology \\ University of Pretoria
}

\begin{abstract}
The focus of the article is to show how the hegemony of heteronormativity compromises attempts at gay-friendly pastoral care and counselling with sexual minorities. Ecclesial resolutions with regard to same-sex relationships are based on Biblical propositions, theologies of heterosexual marriage, and often also on social stereotypes. This article investigates the textual evidence on same-sex intimacy in antiquity in order to demonstrate that views on sexuality and marriage are not fixed, but change over time. It also traces the formation of the theology of heterosexual marriage in the institutionalized Christian religion. Same-sex intimacy during the period from the end of the Roman Republic and the beginning of the Roman Imperial period is discussed, as well as during early Christianity up to and until marriage was sacramentalized. As a consequence of this historical legacy, churches have largely condemned same-sex relationships and have alienated sexual minorities from the faith community. The article contends that the hegemony of heteronormativity is based on an essentialist view on sexuality, as well as a positivist ethical reading of the texts of the New Testament and the contemporary world. It illustrates that the ecclesia itself has not yet been transformed by the gospel message of inclusive love.
\end{abstract}

\section{ECCLESIA AND SEX - A CALL TO WAR OR LOVE?}

In his essay "The Bible, the church and homosexuality" Biblical scholar Dan Via (2003:36) questions the ethics of churches that condemn same-sex intimacy. According to Via, such a lack of flexibility does not have people's well-being at heart, but causes them harm. He calls for a pastoral attitude 
which is considerate of the feelings of people who belong to sexual minority groups. Among them are believing Christians who are also sexually active, but do not experience a tension between their faith and their reality as sexual beings (cf Bird 2000:143). Other individuals are severely affected and harmed by the negative messages from the Christian faith community about who they are, how they may or may not love, and what their value is in the eyes of God. Gay New Testament scholar Dale Martin (1996:130-131) puts is as follows:

\begin{abstract}
Any interpretation of scripture that hurts people, oppresses people, or destroys people cannot be the right interpretation, no matter how traditional, historical, or exegetically respectable. There can be no debate about how the fact that the church's stand on homosexuality has caused oppression, loneliness, self-hatred, violence, sickness, and suicide for millions of people. If the church wishes to continue with its traditional interpretation it must demonstrate, not just claim, that it is more loving to condemn homosexuality than to affirm homosexuals ... Is it really better for lesbian and gay teenagers to despise themselves and endlessly pray that their very personalities be reconstructed so that they may experience romance like their straight friends? Is it really more loving for the church to continue its worship of "heterosexual fulfilment" ... while consigning thousands of its members to a life of either celibacy or endless psychological manipulations that masquerade as "healing"?
\end{abstract}

Martin points out that many gay men are not sick, perverted or effeminate. They are just people who experience same-sex attraction and love. According to him, gays are not harmed by their non-heterosexuality as such, but certainly are harmed when having to deny who they are. Such a denial of selfidentity leads to internalised homophobia (see Dreyer 2006a:155-173; 2007:118). In his book Homophobia: How we all pay the price, W J Blumenfeld (1992) states that sexual minorities are among the most despised groups in the United States. Given the relative openness of that particular Western society, one can just imagine the state of affairs regarding same-sex intimacy in other countries and cultures of the world. Ironic is the paradox between terminology and social practice: “... for many in our society, love of sameness (i.e. homo-sexuality) makes people different, whereas love of difference (i.e. hetero-sexuality) makes people the same" (Blumenfeld 1992:3).

Theologians and exegetes cannot ignore the changes that have taken place in social life from Biblical times, through the ages, to our modern and postmodern worlds (see Dreyer 2006b:445-471). A postmodern view on sexuality is that it is not a homogeneous entity, but the result of an endless variety of ever changing factors. A logical assumption would then be that 
different times and different societies will produce different sexual practices, experiences, values and meanings and that these will always be changing. Rapid sociological, cultural and technological change will keep widening the gap between the Bible and the present time and between our ideas of sexuality and those of the Bible.

Based on the evidence found in the Bible, official ecclesial resolutions on sexuality and marriage impose a heteronormative ideal on believers. Some of these church resolutions do emphasize an affirming pastoral attitude to persons who are not heterosexual, while at the same time condemning all sexual practices outside of heterosexual marriage. The resolutions on samesex relationships are based on Biblical propositions which are determined by heteronormativity. For example, the resolution of the Netherdutch Reformed Church of Africa (NHKA) on homosexuality, October 2007, which pronounces same-sex behaviour a sin and celibacy the only option for gay people.

However, the church's "Study Committee on Homosexuality" presented another resolution (Besluitebundel $68^{\text {ste }}$ AKV, Beskrywingspunt 25$)^{1}$ to the General Synod of the NHKA at its synod in October 2007, but its was not accepted by the synod (my translation from the Afrikaans):

- $\quad$ Hermeneutics (the theory of understanding) helps Christians to "translate" or interpret the Bible which is a premodern document, for today. In the Bible negative culturally determined statements on what is sometimes translated as "homosexual behaviour" can be found. The intention of Scripture is not to make culture normative. The norm of Scripture is that all believers live according to the gospel message. In Protestant churches the point of departure is that salvation is based on faith alone. Nothing in human nature can facilitate this reconciliation. God's Spirit enables believers to dedicate their entire life (including their body) to the service of God.

- Sexual minorities exist. Some of them are members of churches. These believers, as all others, receive pastoral care and guidance from the church for a Spirit-filled life.

\footnotetext{
${ }^{1}$ NHKA 2007. Besluitebundel van die $68^{\text {ste }}$ Algemene Kerkvergadering van die Nederduitsch Hervormde Kerk van Afrika, Oktober 2007, bls 45-48. Pretoria: NHKA Kerkargief (cf htttp//www.nhk.co.za). The "Study Committee on Homosexuality" consisted of Prof Dr T F J Dreyer (DTheol) (chairperson), Dr Johann Beukes (DLitt et Phil, PhD) (secretary), Dr A P J Burger (MHBC), Prof Dr Johan Buitendag (DD, MCom), Prof Dr Yolanda Dreyer (DD, PhD), Ds Gys v R Els (BD, MA Psychology), Dr J F P Engelbrecht (PhD) en Prof Dr A G van Aarde (DD, PhD, D Litt).
} 
- $\quad$ The church believes that all baptised believers are members of the body of Christ. The unity of the church as the body of Christ is an evangelical imperative. Therefore people who belong to sexual minority groups (or to whatever other minorities), like all members, are welcome in the Christian faith community. In light of our understanding of the Word of God, the church assures them with words and behaviour of the love of God and of the faith community.

- In current church practice there is only one kind of life commitment is possible, namely a heterosexual one. The church is requested to do further research on the possibility of other meaningful committed relationships for all people.

An ammended minority report by two elders who were members of the "Study Committee on Homosexuality", dr A PJ Burger and dr J F P Engelbrecht, was put forward as resolution 26 and was accepted as the official policy of the church. After a discussion in which more than 20 members took part and which lasted for approximately three hours, the synod accepted the following amended resolution:

- $\quad$ According to the broader gospel message the Spirit of God enables people to live in God's presence with their whole humanity. This includes homosexual people.

- $\quad$ The church accepts all believers as members of the body of Christ, irrespective of their sexual orientation. The unity of the church as body of Christ is an imperative of the gospel message.

- $\quad$ The church welcomes homosexual people and wishes to comfort and support them. The church will combat all manifestations of homophobia, the hatred of gays and any other form of demeaning behaviour towards homosexual people.

- $\quad$ The church wishes to provide all members, also homosexual members, with pastoral care and moral guidance toward a Spirit-filled life.

- $\quad$ The church, in dealing with the comprehensive phenomenon of human sexuality, should cherish and protect heterosexual marriage as the only form of marriage which was instituted by God. It is the only space within which, according to Scripture, sexual activity, the formation and nurturing of a family can take place. For this purpose God created man and woman. 
- $\quad$ The synod is convinced that homosexual acts constitute sin and, just like all other sins in the Bible, should be confessed.

- $\quad$ God instituted heterosexual monogamous marriage as the space within which sexuality is expressed. Therefore any form of homosexual behaviour and also so-called gay marriage should be rejected by Christian ethics.

- Individuals with a homosexual orientation should refrain from homosexual behaviour, just as all other believers should exercise selfcontrol when it comes to their broken humanity.

In addition, the proposal by the Reverend Lewis Strauss, that certain books by "evangelical-reformed" theologians should be reviewed by the next study committee to serve as the basis for a study guide which will explain the official church policy to members, is accepted. These books are:

- $\quad$ McCafferty, Christine \& Peter Hammond, and Africa Christian Action (South Africa) 2001. The pink agenda: Sexual revolution in South Africa and the ruin of the family. Cape Town: Christian Liberty Books.

- $\quad$ Potgieter, J 2007. Homoseksualiteit: 'n Skrifgefundeerde perspektief. Vereeniging CUM.

With regard to the publication of The pink agenda, the following information was derived from the web page of ACA:

In 2001 the Christian Action for Reformation \& Revival (ACA) published The pink agenda: Sexual revolution in South Africa and the ruin of the family, which exposed radical the homosexual agenda for South Africa. The pink agenda was the first nonpornography book to be censored in the new South Africa (after the first democratic elections in 1994). The restriction was lifted by the Appeals Board after a lengthy battle with the Film and Publications Board. The ACA has opposed homosexual 'marriages' and other attacks on the family with prayer vigils, placard protests, marches, and through presentations at Parliament

(info@christianaction.ora.za)

The "pastoral exegetical" publications of Dutch Reformed minister J G Potgieter are based on his doctoral thesis in New Testament Studies at the 


\section{Pastoral care and gays against the background of same-sex relationships}

University of Pretoria (2004) under the supervision of Prof Dr Jan G van der Watt. Potgieter's work aims to demonstrate that "homosexual relationships of love and commitment were known by the writers of the Bible". He argues that "the anthropology of the Mediterranean people" reveals that "somebody's identity was found in the way he or she lived": "If I have a homosexual relationship, then my identity was homosexual."

([http://www.journals.co.za/ej/ejour_verbum.html]). Potgieter also shows "that permanent homosexual relationships of love and commitment were known among the Greek philosophers", for example Plato, Aristotle and Pausanius who "had permanent homosexual partners." The apostle Paul therefore "knew about permanent homosexual relationships of love and commitment." Potgieter concludes that Paul's problem with same-sex relationships should be carried over to the church today, while the church should, at the same time, promote a gay-friendly pastoral engagement with "homosexuals" (see Potgieter \& Van Huyssteen 2002; 2006:174-185; 2007).

The result of the October 2007 official resolution of the Netherdutch Dutch Reformed Church of Africa is that heterosexual stereotypes become the model for all sexual conduct, including that of sexual minorities. A consequence of this is that, even in progressive churches that do not outright condemn all same-sex practices, "marriage" has also become the ideal and "acceptable relationship" for gays. How marriage has come to assume this position of providing the one and only space for all human sexuality, has a long theological history. Traditionally same-sex intimacy was rejected outright by the Christian church as being "against nature" and therefore against God's creation. This opinion can already be found in the work of Christian emperor Justinian (Nov 72.1), written in 538 CE. Justinian substantiated his view with some Old Testament passages and an appeal to Roman civil law, the Lex Iulia (see Cantarella [1988] 2002:182). Before Justinian used Roman legislature in this way, official views on sexuality and gender relationships had been fairly flexible. In the theological discourse it was Augustine who merged this diversity of thought into one religious system which regulated how people as sexual beings, could become acceptable to God (see Kearney, R [translator] 1999, The works of saint Augustine, part 1, vol 9: Marriage and virginity). He therefore regulated sexuality for the purposes of human salvation - for becoming acceptable to and accepted by God.

Augustine's one-dimensional soteriological system with regard to human sexuality paved the way for Thomas Aquinas's unchangeable sacrament of "eternal holy matrimony". As a sacrament, marital union could not be broken. Marriage was regarded as an unchangeable institution and divorce was prohibited. As a sacrament, marriage was seen as an act of 
salvation, because it served as "medication" (medicinum) and remedy (remedium) against the "deadly disease" of fleshly lust (concupiscence), a term which refers to any form of sex which does not intend procreation (cf Brooten 2003:187, n 11).

Augustine (De civitate Dei XIV.10, 21, 22, in Dyson 1998) saw marriage as a "true and loyal partnership" in which procreation was to be regarded as a gift from God and not as the punishment of sin. Procreation was, for him, the purpose of marriage. Augustine himself never called marriage a sacrament (Witte 1997:22), but he did refer to it as a "sacramental bond" (quoddam sacramentum). As such, marriage symbolised a permanent union (connubi sacramentum - Augustine, On original sin, chapt 39 [xxxiv], in Schaff \& Wace 1952, 5:251; Augustine, On marriage and concupiscence, chapt 11 [x] and 19 [xvii], in Schaff \& Wace 1952, 5:261, 271). Only death could separate married people. Even if the marriage did not produce children, the union could not be dissolved in order for a spouse to try and have children with someone else. For Augustine the order of priorities was: first celibacy, then fidelity in marriage, with procreation in the third place. He interpreted the list of prohibited same-sex acts in Romans 1:26-27 as referring to sex that did not intend procreation (Augustinus, De nuptiis et conupiscentia 20.35). In his work, Epistulae (211.13-14) and in De opera monacharum (32. 40) he condemned same-sex intimacy and said that this is the "unspeakable sin" that is mentioned in Ephesians 5:12, which he declared to be contra naturam in his work, De bono coniugali 10.11-11.12; 8.8 (cf Brooten 2003:181-193 especially $p 187, n 11)$.

According to Augustine (De bono coniugali 17.19), the purpose of marriage is the same "for all people" (in omnibus gentibus), namely to procreate (proles) and for fidelity (fides). He condemned sex for pleasure (conupiscentia) - even within marriage - as fornication, which, along with adultery were regarded as mortal sins (Augustine, De bono coniugali 6.6; 8.8). Sex for pleasure was a sin and classified as para fusin, though it was regarded as the lesser of the immoralities. True "moral sexuality" was celibacy fist and foremost (see De bono coniugali 7.6; 8.8; 9.9; 23.28), and only in the second place came sex within marriage with the purpose of procreation. If marriage partners did not intend procreation they were to refrain from sexual activity.

With marriage gaining salvific significance - making sexual people acceptable to God - and procreation being the sole purpose of sexual activity, it stands to reason that same-sex intimacy, which could not conform to these norms, were declared objectionable. In the wake of this history the ecclesia has become, and is still today, a place where some people are rejected, rather 


\section{Pastoral care and gays against the background of same-sex relationships}

than it being a gathering of people called from the world (ek-kaleo) to mutual love, to follow in the footsteps of Jesus. In rejecting people of a same-sex orientation - often also people who believe in God - the ecclesia shows that it has not yet been transformed by the gospel message of inclusive love. Pastors are caught between their church's attitude towards sexual minorities and the real people to whom they have to minister.

In order to work towards a postmodern flexibility with regard to human sexuality, in order that people will not be harmed, but their well-being served, this article investigates the long history which culminated in present-day Christian views and attitudes. The article demonstrates from earliest Christian writings how the views on sexuality and marriage were forever changing, even then. Biblical texts originated within a cultural context and therefore it is also necessary to explore the attitudes and views of their Umwelt when dealing with biblical texts. The main focus of the article is to revisit data from GrecoRoman antiquity on same-sex behaviour against the background of the ancients' views on marriage and sexuality. Although publications on this topic abound, practical theologians do not often make full use of the results of the work of classicists. However, in light of the exegetical (e.g. Hays 1996:381382, 389-391), and theological (e.g. Jones \& Yarhouse 2000a; 2000b:73-74, 118-119) inferences often made from Biblical and other ancient writings in order to substantiate an official ecclesial rejection of same-sex intimacy while at the same time encouraging a gay-friendly pastoral attitude towards gays, ${ }^{2}$ an overview of existing research results is necessary. For this purpose the article will focus on what historian John Buckler (see Yale University Press' reviews on new books (www.yalebooks.com) describes as "easily the best book on the topic", namely Eva Cantarella's ([1988] 2002) work, Bisexuality in the ancient world. Alan Mendelson (in History: Reviews on new books; see www.yalebooks.com) agrees that Cantarella's book is "an important study that is destined to take its place next to the classic works of Foucault and Pomeroy." My discussion of same-sex relationships in the New Testament and the surrounding world makes extensive use of the work of Cantarella.

The first section of the article consists of a discussion of views on sexuality and marriage in the period from the end of the Roman republic and first-century Roman imperial times, as well as the beginning of the Christian era. The second section critically describes the role of institutionalized religion in the formation of a theology of marriage. In this process marriage was sacramentalized and the act of procreation glorified. The direct result was (and is) the condemnation of same-sex relationships and the alienation of

\footnotetext{
${ }^{2}$ See for example the current official resolution of the Netherdutch Reformed Church of Africa (NHKA) discussed above.
} 
non-heterosexuals from the institutionalized church. The article argues that feeble attempts at a "gay-friendly pastoral attitude" alone are not enough. Unless churches abandon the hegemony of heteronormativity along with its basis, namely an essentialist view on sexuality, which is substantiated by a positivist ethical reading of the Biblical evidence, ecclesial attitudes towards gay Christians cannot be congruent, and therefore credible.

\section{BISEXUALITY AND EFFEMINACY}

By the end of the Roman Republic under the rule of Augustus, the Lex catina officially prohibited sexual practices with boys. Nevertheless it was still common behaviour. Same-sex relationships between adult men were considered a greater problem since that would mean that one of the men would engage in "passive" behaviour, which was not acceptable for a Roman citizen. Such male passivity had to be suppressed by law. However, in the first century some citizens whose credentials were not in question, openly displayed feminine behaviour. They were tolerated and even loved but also made fun of. Julius Caesar was one of them. It was common knowledge that Nikodemes of Bithynia was his lover (see Cantarella 2002:155-156). According to Dio Cassius, Caeser tried to defend Nikomedes against the mockery of the soldiers (Dio Cass 43.20), while Suetonius relates an episode where Caesar did not seem to mind the jabs about his sex-life (Suet Div lul, 22.3). Nonetheless, he was still regarded as a great leader (Cat 11.10). Also among the less illustrious people there are stories of married men with families who used their male slaves sexually (see e g Juven 9. 45-6; Sen, Ep XLVII. 7). According to Cantarella (2002:163) the powerful could best afford to risk being mocked as "passive" or "soft" because they were also powerful. They paved the way for the less powerful to also exhibit similar sexual behaviour without having fear too much dishonour.

Evidence of female non-heterosexuality in ancient Rome (unlike the work of Sappho in ancient Greece) was reported from a male perspective (see Cantarella 2002:164). Such women were seen as rejecting the notion of having to obey their husband and looking to him as their only source of sexual pleasure. Women were considered dangerous and therefore needed to be kept under control. In ancient Greece they were kept out of society and locked away. In ancient Rome they were given an important social task, namely to contribute to the formation of the next generation of Roman citizens. They personally educated their sons and had the task of infusing them with the values of their fathers (see Hallet 1984). Though Roman women enjoyed a much greater measure of freedom and respect than Greek women, they were nevertheless under strict control of men and their reputation had to be 


\title{
Pastoral care and gays against the background of same-sex relationships
}

impeccable. If not, they were severely punished by being humiliated and demeaned. As Cantarella (2002:166) puts it: “... the Romans made their women accomplices and collaborators in an operation which guaranteed the transmission over different generations of a culture which ruled out any autonomous life choices for the female sex."

Same-sex intimacy was seen as the worst form of female wantonness. In Ovid's Metamorphoses it is described as "unnatural" (Ov, Met, 9.737-8; see Foster 1958:26). A woman who was suspected of same-sexual behaviour was accused of adultery (see example in Sen, Contr, 1.2.23). In the Amores of pseudo-Lucian, Caricles who is against male non-heterosexuality uses the argument that, if male non-heterosexuality should be acceptable, then it should also be acceptable for women (Ps Luc, Amores, 28). That would have been unthinkable in Roman culture (see Cantarella 2002:169). The negative view on female same-sex relationships continues in the Christian tradition where it is also regarded as "against nature" and sinful. One of the reasons for God's anger against the heathen is that their women exchanged natural intercourse for unnatural intercourse with one another, according to Paul (Rm 1:26). Augustine (Epist, CCXI) warns nuns against unseemly practices.

Clement of Alexandria (Paidag, III.3.21.3) describes non-heterosexual women as women "who play the man against nature". Cantarella (2002:171) describes why lesbian women posed an even greater threat to Roman society than males exhibiting same-sexual behaviour:

\begin{abstract}
... The most serious crime committed by lesbians was daring to think they could do without men. They were women who rejected the fundamental rule underlying relations between the sexes, the role of nature which had given men alone the power of sexual dominance, not only over women, but also over despised men, such as passive homosexuals. These lesbians were women who questioned the rule according to which men alone were entitled to rule and dominate the world.
\end{abstract}

Roman and Greek men in ancient times often continued with same-sex behaviour after marriage (see Cat, 61; Mart, 11. 68; Mart, 12.97). Many texts attest to the fact that the women often had a problem with that (see Juven, 6.268-72; Mart, 11.43; Petr, Satyr, 69.74-5). However painful the situation may have been on a personal level, these women's social position was not endangered by their husbands' relationship with boys, since they were not socially acceptable relationships and could therefore be no threat to a marriage (see Cantarella 2002:172). 
As far as the law was concerned, non-heterosexual males could not represent others before the law. Having adopted female behaviour by playing the passive role of a woman, such men had caused themselves to lose male privilege. Men who were the victim of rape by robbers or the enemy did not fall into this category (Dig, 3.1.1; 6 [Ulp., 6 ad edictum]. During the first centuries of Roman law there was a progressive hostility towards male prostitution (see Cantarella 2002:173). Male prostitutes paid special taxes. By the third century male prostitution became illegal (see Aur Vict, De Caes, 28. 6). In 390 CE emperor Theodosius introduced strict measures against male prostitution. In the sixth century, according to historian Evagrius, emperor Anastasius I abolished the tax on, among others, male prostitutes (Evagrius, Hist Ecc., III.39). Septimius Severus expected the prefect to ensure that slave owners did not force their slaves into prostitution (Dig, 1.12.1; 8 [Ulp., lib. sing e off. praef. Urbi]). Capital punishment was even introduced for those who corrupted a youth (Pauli Sententiae II.26.13).

\section{BISEXUALITY AND RELIGIOSITY}

Until the fifth century the only persons who were punished for same-sex behaviour were the passive men. Emperor Justinian brought a change to that state of affairs. For him same-sex intimacy was "against nature" and therefore a religious misdemeanour punishable by God (Nov, LXXVII, caput 1, pr). So same-sex intimacy became a sin against God which deserved the double punishment from God and by law. The law became the weapon of the church. Because of God's infinite grace, said Justinian, people who were guilty of these kinds of sins were not to be punished immediately. They would first have the opportunity to confess their sin to the Patriarch and promise never to do it again. However, those who persisted in their sin would be severely punished, even by death. There is no evidence of how these nonheterosexual people were to be killed, either in Novella 77 or the later Edict 141 (see Cantarella 2002:182-184). Documentation on the trials of nonheterosexuals indicates that their punishment was castration (see Dindorf 1931:436). Procopius (Histroria Arcana XI; cf Haury \& Wirth 1963) agrees that this was indeed the punishment and indicates that it was instituted by Justinian. Theophanes (Theophanis Chronographia, ed by C de Boor [18835], 2 vols, Leipzig, p 177 (AM 6021) provides the example of Isaias, bishop of Rhodes and Alexander, bishop of Diospolis who were accused of pederasty, castrated and put on public display.

Cantarella (2002:186) summarises the development of punishment for same-sexual behaviour as follows: in 342 CE Constantius and Constans declared that passive non-heterosexuality should be punished with a special 


\section{Pastoral care and gays against the background of same-sex relationships}

punishment, which probably was castration. In 390 CE Theodosius I declared that passive non-heterosexual male prostitutes should be burned alive and in 438 CE the Theodosian Code included all passive non-heterosexual males in this punishment. Lastly Justinian included all active forms of same-sex intimacy and the punishment was death, though the form of death is unknown to us. The question is to what this progressive repression of a phenomenon which had been tolerated for a long time, should be attributed. According to Cantarella (2002:186) "[i]nevitably one seeks an explanation in Christian teaching, to which Justinian explicitly links his condemnation, where ... he defines homosexuality as a sin which offends the Lord. By Justinian's time, the patristic writers had worked out a theology of sexuality which condemned relations between persons of the same sex as being 'against nature'”.

\section{CHANGES IN SEXUAL ETHICS}

\subsection{Paganism}

According to Paul Veyne (1978:36ff), between Cicero and the time of Antonines the Roman view on sexual relationships changed fairly drastically and ended up being similar to the later Christian ideas on marriage, though he denies any Christian influence. The changes were the result of a transformation of the Roman ruling class. Previously the noblemen had the power to do as they pleased, whereas later they no longer had unlimited control. As subjects of the prince the noblemen were one another's equals, had to show respect and get along with one another. A new morality was the result of these changes Cantarella (2002:188; see Veyne 1978:36-36) describes late pagan morality in Roman times as follows:

Before Christianity became widespread ... Roman sexual morality had changed form bisexuality, based on aggressive gratification, into heterosexuality based on reproduction. Late pagan sexuality ... was in principle limited to matrimonial intercourse. Chastity (outside marriage) had become a virtue. Marriages had multiplied. Marital relations had changed: husbands and wives were supposed to love each other, and discord in the home was not tolerable. In short, the "morality of couples" had come into being.

With this change came a different view on non-heterosexual and heterosexual behaviour. The focus was now on the latter (Veyne 1978:38).

Christian teaching fit well into this context where the Stoic idea of controlling one's impulses provided an additional incentive to behave in a "moral" fashion. To this Aline Rouselle ([1983] 1988:12) adds the insight that sexual 
activity was seen as a health risk in the first and second centuries. Celibacy was therefore regarded as healthy. Soranus (I, 30-1) described sexual activity as harmful. Men who did not participate in such activities he regarded as much stronger than their counterparts. Doctors such as Rufus, Galen and Oribasius advised their patients who were chronically tired and anxious to exercise, eat healthy food and refrain from sexual activity (see Cantarella 2002:189). Their sedentary city lifestyle had taken its toll. Restraint and abstinence were generally in vogue. Even the Epicureans who focused on earthly happiness and pleasure, were suspicious of sex. Epicurus (Diog Laert, $X .119,132$ ) found that sex could be dangerous, pleasure did not lie in sensuality, and one should not get married, if at all possible. The Cynics were also suspicious when it came to sex and marriage (see Finley 1968:94). According to Musonius Rufus in the first century the only good reason for having sex was procreation. Even in marriage he regarded sex as wrong. Because there was no procreation involved, he rejected same-sex activity as sterile (see Hijamans 1963:71-77).

Christianity came into being in an environment where ascetism was highly valued. These values seemed to have rubbed off on Christian communities (see inter alia Von Harnack [1886-9] 1909-10; Grant [1888] 1957; Swain 1916; Leipoldt 1961:60; Bullough 1976:159; Crossan 1998:265271, 283-284). Cantarella (2002:191) poses the question whether Christian sexual ethics and specifically its condemnation of same-sex intimacy is the consequence of late pagan ethics. Before one can come to any conclusion in this regard, the Israelite roots and Christian doctrine itself will first have to be investigated.

\subsection{The Judeo-Christian tradition}

Christian teaching condemned non-heterosexual activity, whatever its form, from the very beginning, states Cantarella unequivocally (2002:191, cf Bailey [1955] 1975; McNeill 1976; Boswell 1980; Scroggs 1983:99-122), though Biblical references concerning the matter are few. In Romans (1:26-27) Paul denotes same-sex behaviour as the reason why God's anger was unleashed on the pagans. The argument that Paul is referring only to male prostitution here, does not hold, says Cantarella (2002:191; cf Bailey [1955] 1975; Boswell 1980:107, 341), since that would only account for the reference to male behaviour. When Paul speaks of female same-sex behaviour, he does so in broader more general terms and substantiates his view with the argument that such behaviour goes "against nature". The same goes for male non-heterosexual behaviour. Furthermore, Paul does not refer to prostitution in his First Letter to the Corinthians. Among those who will not have a part in 


\section{Pastoral care and gays against the background of same-sex relationships}

the kingdom of God are the malakoi and the arsenokoitai (1 Cor 6:9), which are the molles and the masculorum concubitores in the translation of Jerome. Non-heterosexual behaviour is distinguished in two categories: those who are passive, namely the malakoi and those with an active role, the arsenokoitai, which means that Paul condemns every form of non-heterosexuality, deduces Cantarella (2002:191-192), who sees Paul's language in this regard as straightforward. Some, she points out, interpret the text in a narrower sense than a simple reading would suggest. One such opinion is that Paul refers only to pederasty which had at the time had much deteriorated, and Paul would have wanted to protect young boys against such harassment (see Scroggs 1983:101-109). In order to support this idea the malakoi are interpreted as the boys who were treated badly and the arsenokoitai the adult men who exploited them (see Boswell 1980:106-139; Scroggs 1983:62-65 for malakos-malakia and 106-107 for arsenokoitai). Cantarella (2002:192-193) rejects this argument for a few reasons. In the first instance the malakoi did not refer to young men, but to the pathetic passivity of adult males. The word which originally meant "soft" took on the negative connotation of "effeminacy". That would not be applicable to a boy since he had never been a man in the first place. Paul therefore condemns not only active same-sex behaviour as was the case in earlier times, but all non-heterosexuality, be it active or passive, male or female. The old tension between active and passive is now replaced by a new tension between heterosexuality and non-heterosexuality. For Paul it is not about masculinity and honour as was the case in the GreekRoman world, but it was rather a matter of kata physin or para physin. Heterosexuality was the norm and therefore obligatory for all. Anything that deviated from that norm was considered "abnormal" or "deviant". In the Israelite tradition people were classified from holy, to less holy, to impure for the purposes of marriage arrangements (see Jeremias [1962]1969:271-273).

In this way Paul established a new sexual ethics which was uncritically followed by authors for many centuries to come. This "new morality" can be seen again in a pastoral letter to Timothy (probably early second century) (see Scroggs 1983:66; Von Harnack 1902). The subject is "the law" and among those who transgress are the pornoi, arsenokoitai and the andrapodistai in (I Tm 1:9-10). There is no longer a reference to malakoi (molles). Those who are condemned are not only the pornoi, the male prostitutes but all who exhibit same-sex behaviour, the arsenokoitai. Cantarella (2002:193-194) poses the question where this "new ethical system" which was taking shape in early Christianity, came from - either from an ancient pagan or an ancient Hebrew tradition. 
Interpretations of Old Testament texts which may have a bearing on what we today term "homosexual behaviour", differ quite substantially as well. According to some, Hebrew culture did not condemn non-heterosexuality as such, but only prostitution and sexual violence (see Bailey [1955] 1975; McNeill 1976; Boswell 1980; Scroggs 1983:99-122; Hörner 1974, 1978). Cantarella (2002:194) terms these "forced interpretations". The passage in Deuteronomy 23:17-18 cannot be used in the case of same-sexual behaviour, because it refers to prostitution. All kinds of prostitution are condemned in Deuteronomy. Leviticus 18:22 expressly forbids non-heterosexual behaviour. The fact that there is no mention of female same-sexual behaviour does not give sufficient cause to deduce that this text is not a condemnation of nonheterosexuality per se, contends Cantarella (2002:195). Even though the Sodom story (Gn 19:4-11) and the story of the Levite (Jdg 19:1-30) are about the male rape of other males in a context of power, they also do not disprove her view that the Old Testament condemns non-heterosexual behaviour in all its forms. Cantarella (2002:198) looks to Palestinian and Greek post-Biblical traditions in order to confirm that a condemnation of same-sexual behaviour is already present in the Bible.

In Palestinian tradition the Mishnah (circa 200 CE) shows that nonheterosexual deeds were punished by stoning (Sanhedrin, 7.4). The death sentence was only for those who perpetrated the act deliberately (Keritoh, 1.2). If a person was a minor or asleep, the adult and the person who was awake was the one to receive the death penalty (Keritoh, 2.6). The Talmud (circa $600 \mathrm{CE}$ ) which interprets both the Mishnah and Scripture (see Neusner 1986), takes Leviticus 18:22 to means that the person who plays the active role is punishable. Leviticus 20:13 which utilizes the same verb, is taken to mean that both persons should be killed. This indicates that passive nonheterosexual behaviour is also condemned. Cantarella (2002:198) confirms: "The Scriptures therefore condemn any manifestation of homosexuality" (see Babilonian Talmud: Sanhedrin 54a-54b; see also Bailey [1955] 1975:61-63; Scroggs 1983:77-79).

As far as female non-heterosexuality is concerned, both Scripture and the rabbis do not say much, maybe because it was not seen as important to society. One test case where the schools of Hillel and Shammai differed, was whether a woman who had had sexual relations with another women could marry a priest (who could only marry a virgin). The Shammai school considered sex to be sex. Such a woman would be unfit. The Hillel school found that there was no reason why such a woman could not marry a priest (Palestinian Talmud, Gittin 49 and 70; see Epstein 1942:308). 
The Greek tradition on the topic can be seen from the works of Philo of Alexandria and Flavius Josephus. Philo was a theologian and philosopher who was born circa 20 BCE. When referring to Sodom, Philo sees what happened there as sexual sin (De Abrahamo, 133) and he condemns such deeds as "against nature" and a waste of sperm. The penalty was death (52 Philo, Hypot, 7.1). For him it was not so much a legal matter as a moral one (Siegfried [1875] 1970). Both Philo and the historian Flavius Josephus condemned every type of same-sexual behaviour, insisting "that homosexuality is a pagan vice, not a Hebrew one" (Cantarella 2002:200). This same insistence can be found in Palestinian tradition. That the Israelite people had already been "tainted" by the "pagan vice" of non-heterosexual behaviour by the second century BCE is attested to by The Testaments of the Twelve Patriarchs (written between 153 and 109 BCE) (see Charles [1908])1966:xliixliv). In the Testament of Levi (XVII.11) a prophesy warns that priests will become, among others, "violators of children" (paidophtorol) (see Cantarella 2002:201). The Testament of Naftali III.4) warns that Israelites should not be like the gentiles and commit the sin of Sodom, which is same-sex behaviour (see Charles 1896).

According to Cantarella (2002:201-202) Christian condemnation of non-heterosexuality started with Paul and has its roots firmly in Judaism. Recent attempts to indicate that condemnation is limited to certain kinds of same-sexual behaviour are not convincing. Cantarella (2002:202) calls it a "centuries-old tradition, constant and coherent, the traces of which go back at least as early as the sixth century $\mathrm{BC}$." She cites the main reason for this aversion as: "how intolerably criminal any wastage of male seed was for the Jews" (Cantarella 2002:202; cf Bullough 1976:78-86; Symonds 1986:6). This also explains why female same-sexual behaviour was not considered a big problem. It did not interfere with the survival of the nation.

\subsection{The Christian synthesis}

Was the policy of Christian emperors regarding same-sexuality influenced more by the "new pagan sexual morality" or was it an attempt to conform to Christian teaching, asks Cantarella (2002:203). She points out that the late pagan attitudes towards non-heterosexual behaviour and Christian attitudes ("against nature") are not the same.

Musonius Rufus (Musonius Rufus and Greek Diatribe 71-77) frowned upon same-sexual behaviour, not because it was "against nature", but because it did not involve procreation. Heterosexual relations not aimed at procreation, were similarly unacceptable. The medical perspective of Rufus of Ephesus was that male non-heterosexual behaviour was more violent and 
more exhausting and therefore not good for the health (see Rousselle 1983:12). The objection against same-sexual behaviour was more practical than moral. For Soranus non-heterosexuality was a disease, but Cantarella (2002:204) points out that the disease lay not in being attracted to someone of the same sex, but in passivity.

Parmenides elaborated on the causes of this disease which he saw as hereditary. People were born neither man nor woman. The disease was transmitted through semen. It could affect anyone and a person could do nothing about it. There was no cure. The disease worsened over time, because, as the body became older and energy waned, such a person would develop a greater tendency toward passivity (Cantarella 2002:204; see Drabkin 1950:900-905; Schrijvers 1985). In general in antiquity a lack of masculinity was deemed a disease. Same-sex intimacy was that kind of disease and not in itself an unacceptable expression of sexuality. Active nonheterosexuality was not so much of a problem. When passivity and effeminacy came into play, it was deemed a problem. In Artemidorus' Book of dreams (circa $2 \mathrm{CE}$ ) the concerns of the ancients concerning same-sexual behaviour, become clear: same-sexual dreams are categorised as "according to nature". Then the question is: was the partner in the dream a free man or a slave? Dreaming about sex with a free man was better than with a slave. If the partner was a slave the question would be whether the one who had the dream had possessed the slave or was possessed by the slave. The former was acceptable, the latter not. If the person about whom the dream was, was a stranger the question is whether he was older and richer or younger and poorer. The former was acceptable and the latter not. Therefore, same-sexual dreams were socially acceptable if the person having the dream was not demeaned in any way according to the social standards of the day (see Cantarella 2002:204-205). Cantarella (2002:206) points out that the only nonheterosexuality considered "unnatural" in the Book of dreams was that between women (along with sex with oneself) and interprets it as follows: "This classification fits perfectly into the male vision which sought to repress female sexuality ... By identifying only intercourse between women as 'unnatural', this approach confirms ... that sexual relations between men were not unnatural." Pseudo-Lucan (Amores, 20) and Plato (Leges VIII.7.839a) did regard same-sex behaviour to be "against nature". Plato's specific concern was procreation. Pseudo-Lucan (Amores, 35) provides a different explanation: heterosexuality is indeed "natural" since the phenomenon can be observed among animals. Human beings are, however, more than animals. Nonheterosexuality is a cultural phenomenon and therefore superior to "natural" heterosex. The late pagan "new morality" differed quite substantially from the 


\section{Pastoral care and gays against the background of same-sex relationships}

earlier pagan morality because of internal changes that had taken place. Cantarella (2002:206-207; see Von Harnack 1902:12ff) comments as follows on where Christianity fit into the picture:

The spread of Christian morality would be incomprehensible if one had to image it clashing with a radically different style of life and set of philosophical principles. To some extent, the new morality had to satisfy requirements felt by pagan society, responding to needs which were certainly complex and difficult to define, but undeniably real. Christianity was clearly able to give an adequate response to these needs.

Early Christianity's idea of sexual restraint being a good thing and sexual abstinence even better (cf 1 Cor 7:8-9; Mt 19:12), seems to have fit in fairly well with its environment. According to Matthew 19:12 Jesus says to his disciples who wanted to know if it would be better not to marry at all: "Not all men can receive this precept, but only those to whom it is given. For there are eunuchs who have been so since birth, and there are eunuchs who have been made eunuchs by men, and there are eunuchs who have made themselves eunuchs for the sake of the kingdom of heaven. He who is able to receive this, let him receive it." Cantarella (2002:207) interprets this as that, for Jesus, virginity was an alternative to marriage but not necessarily superior to it. She points out that the words "he who is able to receive this, let him receive it" was translated into Latin by Jerome and interpreted as: "he who is able to do this, let him do it". The translation then does seem to imply that virginity is a sought-after quality and should be appropriated by all who are able to do so. Cantarella (2002:2007-2008; ${ }^{3}$ cf Epsein 1948; Bullough 1976:74ff) concludes:

The rejection of sexuality, in short, was a very strong component in Christian culture, and fitted in perfectly with the late pagan trend towards ascetism. A close examination shows that in this field Christianity was closer to late pagan morality than to Jewish morality. The Jewish tradition gave sex more importance than was allowed by Christian ethics ... when it comes to heterosexual intercourse, Jewish culture was certainly less repressive than Christian culture ... one can basically state that sexuality in the Jewish world was not only tolerated, but recognised.

However, the Christian condemnation of same-sex behaviour did follow Hebrew tradition in the respect of regarding it as "against nature", wicked and

\footnotetext{
${ }^{3}$ Cf also Cantarella, E [1985] 1987. Pandora's daughters: The role and status of women in Greek and Roman antiquity, $\mathrm{p}$ 161).
} 
a sin before God. Cantarella (2002:208; see Lactantius' Divine Institutions VI.23.10; Augustine's Confessions III.8; Tertullian's De pudicitia.) describes the Christian "contribution" as follows:

\begin{abstract}
Christianity adds to the pagan disapproval of male sexual passivity the Hebrew disapproval of active homosexuality (as well as the passive variety), and goes so far as to issue a global condemnation of all sexual intercourse between people of the same sex. Falling within a more general framework of the rejection of the "pleasures of the flesh" (which were later demonised by the Fathers of the Church), this condemnation further restricted the space allowed for sexuality, definitively and drastically limiting the sphere of lawful intercourse to marital sex for procreative purposes.
\end{abstract}

Did Christian teachings on sexuality influence legislation and punishment since the proclamation of Christianity as state religion? Cantarella (2002:208) points to the "gradual hardening, and especially the extension of the range of types of homosexual behaviour to be punished" in the legislature that could have been influenced by Christianity. On the other hand she draws attention to the fact that punishments would have been much harsher than they actually were, had legislation really conformed to Christian principles. The first indication of a merger between legislature and Christian principles can be found with Justinian ( $6^{\text {th }}$ century), in other words a full three centuries after Christianity was declared the state religion. Before Justinian, only passive non-heterosexuality was punished. Cantarella (2002:209) explains this as that "the imperial authorities found themselves legislating in a world which for many centuries had not only accepted, but respected and admired active homophilia". It would have been difficult to go against popular views and attitudes. The gradual hardening of the laws and punishment may have been a compromise towards a more Christian ethic. Another example is the way in which a marriage could be dissolved under Roman law simply when both parties agreed on the matter. Here too, a sudden clamping down on this practice to bring it in line with Christian teaching would have created a problem. A gradual progression towards a stricter policy by the state can be seen. The emperor who finally did bring state policy in line with Christian teaching was again Justinian (Cod, V.17.11), who in 542 CE introduced punitive measures for communi consensu - divorce on the grounds of mutual agreement rather than divorce based on a fault committed by one party, or on an external problem such as impotence (Nov, CXVII). This law was so unpopular that Justinus II, Justinian's successor, had to have it withdrawn in 566 CE. Cantarella (2002:209-210) concludes that the policy of the state was 
oriented toward imposing Christian morality, but it had to do so gradually: first punishing only passive non-heterosexual behaviour until Justinian later clamped down on all forms of same-sexual behaviour, on account of it being "against nature" and an offence to God.

\section{CONSEQUENCES}

Greek and Roman views on sexuality and same-sex intimacy differed in some respects and were similar to a certain degree. The sexual ethics of the ancient world in which Christianity found itself was a complex matter. For the Greek male non-heterosexual relationships were part of his life experience and was regulated by social norms. These experiences were both legally and socially acceptable. Some caution was exhibited to ensure that pederasty did not damage the future of young boys who were to become respected citizens and strong, active men. Cantarella (2002:211-212), however, does see Greek sexual ethics as repressive on account of the view that female sexuality was to be controlled and subjected to the power of men. If maleness was the norm, female sexuality that was not in service of males, was suspect.

Given the abundance of bisexual divinities in Greek culture, one can deduce that there was an awareness in Greek culture of homo- and heterosexual tendencies in males (see Delcourt 1958). Rituals and festivals where males and females reversed roles by changing into the clothes of the other sex, were common, for example in Argos (Plut, De mult. virt., $245 \mathrm{E}$ ), in Sparta (Plut, Lyc, 15.5) and in Cos (Plut, Quaest Graec 304 E). Bisexual impulses could however only be expressed in certain ways: with the right person, in the right way and according to the rules. Boys had to behave in a certain way. They were the "desired object", which was both flattering to them and a social obligation with which they had to put up, while conducting themselves in the appropriate way. That meant not being "too easy". When they became men they had to revert to the active role, becoming the "desiring subject" in what Cantarella (2002:214) calls a "rigorously heterosexual society". This transition was not necessarily smooth or easy, especially if a man discovered within himself a tendency toward passivity. Cantarella (2002:215) makes the observation that "[s]tatements which are often taken as condemning homosexual relationships can more properly be seen as expressing an awareness that it was not always easy to cope with this experience ... Given this situation one has to speak with a certain degree of caution, in the Greek context, about the free expression of bisexuality."

Sexual ethics was simultaneously a moral, social, cultural and political norm in ancient Greece. Cantarella (2002:215-216) criticizes Michel Foucault's idea that Greek sexual morality was "the expression of an 
individual moral code, a rule of contincence, measure and self-control which was independently and freely chosen by individuals." In doing so "he transforms a kind of censorship to an expression of freedom." She points out that the fact that there were no legal rules does not mean that people had to rely only their freely-chosen self-discipline concerning sexual matters. Cantarella (2002:216) explains it as follows:

[T]he Greek homosexual code (even in the absence of legal rules) was not purely an internal code. The absence of legal rules did not mean an empty space, a territory open to the expression of freedom. The fact that the law did not punish homosexuality did not mean that homosexuality could be expressed without restraint: the restraints had been in place for centuries, sinking their roots into the pre-city past of Greece (when they had served as institutional restraints), while in the age of the cities they changed into a rigorous and detailed social code, imposing from the outside a very precise and detailed paradigm of experience, and limiting its freedom. Not even in the freedom of Greece was sexuality experienced in a world without frontiers.

Quite the opposite: sexuality in Greece was highly structured. The unwritten rules on when, with whom, and how one could engage in sexual practices most probably did not coincide with people free desires and "natural" orientations. This makes Greek sexuality particularly difficult to understand (see Cohen 1987).

In Roman society it was also deemed "normal" for a man to have sexual relations with both females and males. As in Greek culture, the Romans equated masculinity with the active role. Their views differed from the Greeks in that they did not think that it was at all educational for young boys to play the passive role at a certain stage in their lives. They saw boys as potential males who should never be subjugated, especially not, as Cantarella (2002:217) puts it, "during a delicate period such as adolescence." For Roman males it was of the utmost importance to exercise power over others. Being the persons with all the power, they also had the power to give others pleasure when they wanted to - which, according to Cantarella (2002:217), was not often. She also connects this attitude to the Roman male's inability to comprehend why a woman would prefer another woman sexually to a male. Such women had to be "nothing but poor mad girls, or such females who tried vainly and outrageously to usurp the male prerogatives" (Cantarella 2002:217).

In Rome a boy was already considered an adult at fourteen years of age and, if he were sui iuris (a paterfamilias), he could take a wife. If a Roman 


\section{Pastoral care and gays against the background of same-sex relationships}

boy would exhibit same-sexual behaviour it would have been considered a great setback for his moral and political formation. For this reason in Rome, different from Greece, there were laws against pederasty from the Republican period onwards (see Cantarella 2002:218). The punishment was a fine. This, however, does not mean that non-heterosexuality as such was forbidden. Roman males needed to exhibit virility. Women alone were not enough. Two categories of men were available to them, namely slaves and prostitutes. Slaves had to do their master's bidding, whatever that was, and prostitution was not forbidden in the early Roman period. Roman same-sex intimacy was a matter of exerting power over others, always in an active role and, as such,

[m] uch less complex and sophisticated, entirely lacking in the role tension which characterized its Greek counterpart, the sexual life of a Roman had only one basic rule: being a male and proving you were a male, never undergoing the humiliation of serving others, making sure that others "served" you, the proud victor, the soldier and the lover who always and everywhere swept all before him, in love as in war.

(Cantarella 2002:218)

In the Hellenistic period, however, things changed somewhat. The love of boys, rather than simply dominating and possessing other men, came into play. This is not the same as Greek pederasty though. The Romans did not have a tradition of forming and education boys also by means of sexual experience. Cantarella (2002:219) sees Romans as not particularly good with courtship. Though she believes that the Romans did love their boys, a boy yielding to a Roman man, would also reinforce his virility and dominance. His self-image could thus remain intact in spite of his expression of bisexuality. However, passive non-heterosexuality did become fashionable in Roman circles. Cantarella (2002:220) attributes this to Greek influence and the influx of foreigners and freed slaves into Rome. She sees the influence as that this contact with the Greeks and others "simply helped them [the Romans] to abandon themselves with greater ease and fewer problems to personal tendencies which, within the original framework, had had to be rigorously repressed." For the Romans this was a time of crisis. Their well-structured society was changing dramatically. Previous roles and orientations were no longer relevant. According to Cantarella (2002:220) "The disorientation was all-embracing". She points out that the self-image of the ever powerful Roman male must have been difficult to live up to. Only the most powerful, such as Julius Caesar in his relationship with Nicodemes, dared to admit publically to sexual passivity in their private lives. For ordinary people this would not have 
been possible. Rome could not become a city "where adult men prostituted themselves in brothels, where vice was rampant, where men were no longer really men" (Cantarella 2002:221). This would have gone against the grain of the traditional as well as the new Christian ethics. Whereas the pagan concern was with "active" and "passive" roles, the Christian concern was with the "naturalness" of heterosexuality and the condemnation of all forms of same-sex behaviour. In conforming to Christian ethics Christian emperors went against the age old Greek-Roman concept of masculinity and male virility. The compromise was first the full condemnation of passive nonheterosexual behaviour, punishable by death at the stake (in 438 CE under Theodosius II). Then Justinian imposed Christian ethics in full force and made sure that sin against God which was sin against the natural order that God had created, was punished by death. Throughout the ages, Cantarella (2002:222) points out, it was "according to nature" for women to be dominated and subjugated by men and for men to dominate both women and other men. With the advent of Christian ethics "nature no longer allowed them any alternative choices: the only act 'according to nature' was heterosexual intercourse". Heteronormative views in antiquity provided the foundation for the theological arguments that same-sex behaviour is contra naturam.

\section{DECONSTRUCTING HEGEMONY}

Due to the influence of Romanticism, Humanism and Liberal Theology the contra naturam argument changed over time. Procreation which had long been seen as main purpose of marriage (which was instituted by God) and of all sexual activity, was dethroned. Gradually this led to an acknowledgement of sexual pleasure in the intimate relationship between a heterosexual married couple (see Dreyer 2005:729-751). In progressive circles, including ecclesial institutions, a more gay-friendly approach has recently led to the mostly conditional acceptance of sexual minorities.

However, what has remained is that gays should still conform to the social values determined by a heteronormative perspective on sexuality. When it comes to morality, the institutionalized church is notorious for its tendency to coerce people into conformity. If it should continue to operate on this level, the institutionalized church would fail to recognize and acknowledge the plurality of the present-day "global village", which is one of postmodernity's most distinctive characteristics. Various cultures and societies produce various values and practices and these keep on changing over time. Views or values concerning morality, sexuality and marriage never remain "fixed for all time". This has been the case since the earliest "European Law Code", written in stone in fifth century BCE at the ekklesiasterion (circular agora) of the 


\section{Pastoral care and gays against the background of same-sex relationships}

ancient city Gortyn in Crete, in which the "preference of men over women" was regulated, but which also gave both the wife and the husband the right to divorce (see Vasilakis [2008]:49-55). This is the case today when judiciary measures regulate intimate relationships, also of non-heterosexual people. These ever-changing "laws" of social behaviour include values regarding family, sexual ethics and relationships such as marriage.

The present-day ecclesia is challenged to respond officially and in a positive and creative way to postmodern philosophical and theological discourses which have exposed the hegemony of the heteronormativity so inherent to ecclesial practice. Only when traditional heterosexual and nonheterosexual stereotypes are discarded, can pastoral theology become authentic when dealing with sexual minorities. Then pastors will no longer find themselves in the double bind of trying to marry an authentically gay-friendly pastoral attitude and an authentically Christian attitude of loving the other, with the official ecclesial condemnation and rejection of people because of their same-sex love relationships.

An appreciation of the social dynamics of antiquity with its constant changes with regard to views, laws and practices concerning sexuality and marriage, can help to relativize existing stereotypes and to deconstruct the heteronormative hegemony prevalent in ecclesial circles and in society. Sofia Souli ([2008:93]) approached her study of the love life of the ancient Greeks with such a careful attitude:

If we sought right from the beginning not to fall into the trap of prejudice and prejudgment, which are never productive, it was because whatever weaknesses we happened to note in the ancient Greek world, there was not only no other society at that time to compare to it, but it also had a number of exceedingly strong points that would be still worth promoting today to secure a better life.

Understanding the impact of Christianity on the morality of antiquity (and vice versa), combined with a critical approach to the ideological concerns of churches today when they condemn some and mystify and sacramentalize other customs of sexual intimacy, can open possibilities for change. Such change can help to nurture an authentic gay-friendly pastoral attitude in both ecclesial institutions and individual pastors. Such an attitude could at last replace outdated scholastic prejudices.

Awareness of all of the above, would challenge theologians to reflect on appropriate pastoral models and methods with which to help to empower pastors for their engagement with non-heterosexual people who do not want to conform to the stereotypes to which they have for so long be confined. 
Stereotyping deepens the wound of internalized homophobia. Inclusive practical-theological theories ensuing from a postmodern paradigm can offer pastoral models and appropriate methods by means of which pastors can uphold the authority of the gospel of love when ministering to vulnerable people who long to also feel at ease in the presence of God and in the faith community. This is the challenge to pastoral theology.

\section{Works consulted}

Augustine [s a] 1952. Sermons on New Testament lessons, Sermon 1.22, in Schaff, $\mathrm{P} \&$ Wace, $\mathrm{H}$ (eds), A select library of Nicene and Post-Nicene fathers of the Christian Church. Grand Rapids, MI: Eerdmans.

Augustinus [s a]. De civitate Dei, XIV.10, 21, 22, in Dyson, R W 1998, Augustine, city of God, ed \& tr by R W Dyson. Cambridge: Cambridge University Press.

Augustine [1999]. The works of Saint Augustine, part 1, vol 9: Marriage and virginity, tr by R Kearney. Hyde Park, NY: New City.

Augustinus [2003a]. De nuptiis et conupiscentia, in Brooten B J 2003, Nature, law, and custom in Augustine's On the good of marriage, in Matthews, $S$ et al (eds), Walk in the ways of wisdom: Essays in honor of Elisabeth Schüssler Fiorenza, 181-193. Harrisburg, PA: Trinity Press International. (A Continuum imprint.)

Augustinus [2003b], De bono coniugali, in Brooten B J 2003. Nature, law, and custom in Augustine's On the good of marriage, in Matthews, $S$ et al (eds), Walk in the ways of wisdom: Essays in honor of Elisabeth Schüssler Fiorenza, 181-193. Harrisburg, PA: Trinity Press International. (A Continuum imprint.)

Bailey, D [1955] 1975. Homosexuality and the Western Christian tradition. Reprint. Hamden, CT: Shoestring Press.

Bird, P A 2000. The Bible in Christian ethical deliberations concerning homosexuality: Old Testament contributions, in Balch, D (ed), Homosexuality, science, and the "plain sense" of Scripture, 142-176. Grand Rapids, MI: Eerdmans.

Boswell, J 1980. Christianity, social tolerance and homosexuality: Gay people in Western Europe from the beginning of the Christian era to the fourteenth century. Chicago, IL: Chicago University Press.

Brooten, B J 2003. Nature, law, and custom in Augustine's On the good of marriage, in Matthews, $\mathrm{S}$ et al (eds), Walk in the ways of wisdom: Essays in honor of Elisabeth Schüssler Fiorenza, 181-193. Harrisburg, PA: Trinity Press International. (A Continuum Imprint.)

Blumenfeld, W J 1992. Homophobia: How we all pay the price. Boston, MA: Beacon.

Bullough, V L1976. Sexual variance in society and history: Classical sources of Christian hostility to sex. Chicago, IL: Chicago University Press.

Cantarella, E [1985] 1987. Pandora's daughters: The role and status of women in Greek and Roman antiquity. Manchester/Baltimore, VT: John Hopkins University Press.

Cantarella, E [1988] 2002. Bisexuality in the ancient world. 2nd ed \& tr by C Ó Cuilleanáin. New Haven, MA: Yale University Press. 
Cohen, D, 1987. Law, society and homosexuality in classical Athens. Past and Present 117(1), 3-21.

Crossan, J D 1998. The birth of Christianity: Discovering what happened in the years immediately after the execution of Jesus. San Francisco, CA: HarperSanFrancisco.

De Boor, C (ed) 1983-5. Theophanis Chronographia, Vol 1. Leipzig: Breitkopf und Hirtel. (AM 6021.)

Dindorf, L (Hrsg) 1931. Johannis Malalae Chronographia. Bonn: Weber. (CorpusScriptores Historia Byzantinae.)

Drabkin, I E (ed) 1950. On acute diseases and on chronic diseases. Chicago, IL: Chicago University Press.

Dreyer, Y 2005. Sexuality and shifting paradigms - setting the scene. HTS 61(3), 729-751.

Dreyer, Y 2006a. Prejudice, homophobia and the Christian faith community. Verbum et Ecclesia 27(1), 155-173.

Dreyer, Y 2006b. Heteronormatiwiteit, homofobie en homoseksualiteit - 'n roetekaart vir 'n inklusiewe kerk. HTS 62(2), 445-471.

Dreyer, Y 2007. Hegemony and the internalization of homophobia caused by heteronormativity. HTS 63(1), 1-18.

Epstein, L M 1942. Marriage laws in the Bible and the Talmud. Cambridge: Cambridge University Press.

Finley, M I 1968. Aspects of antiquity: Discoveries and controversies. London: Chatto $\&$ Windus.

Foster, J 1958. Sex variant women in literature. London: Routledge.

Grant, F C [1888] 1957. The influence of Greek thought on Christianity. New York: Liberal Arts Press.

Hallet, J 1984. Fathers and daughters in Roman society: Women and the elite family. Princeton, NJ: Princeton University Press.

Haury, J \& Wirth, G (eds) 1963. Procopius: Histroria Arcana, XI. Leipzig: Teubner.

Hays, R B 1996. The moral vision of the New Testament: Community, cross, new creation: A contemporary introduction to New Testament ethics. San Francisco, CA: HarperSanFrancisco.

Hijamans, D L (ed) 1963. Musonius Rufus and Greek diatribe. Assen: Van Gorcum.

Jeremias, J [1962] 1969. Jerusalem in the time of Jesus: An investigation into economic and social conditions during the New Testament period, tr by F H \& $\mathrm{CH}$ Cave from the $3^{\text {rd }}$ German edition. London: SCM.

Jones, S L \& Yarhouse, M A 2000a. Homosexuality: The use of scientific research in the church's moral debate. Downers Grove, IL: InterVarsity Press.

Jones, S L \& Yarhouse, M A 2000b. The use, misuse and abuse of science in the ecclesiastical homosexuality debates, in Balch, D (ed), Homosexuality, science, and the "plain sense" of Scripture, 73-120. Grand Rapids, MI: Eerdmans.

Kearney, R (translator) 1999. The works of Saint Augustine, part 1, vol 9: Marriage and virginity. Hyde Park, NY: New City.

Leipoldt, J 1961. Griechische Philosophie und frühchristliche Askese. Berlin: Alfred Töpelmann. 
Martin, D B 1996. Arsenokoitês and malakos: Meanings and consequences, in Brawley, R L (ed), Biblical ethics \& homosexuality: Listening to Scripture, 117136. Louisville, KY: Westminster.

McCafferty, C \& Hammond, P and Africa Christian Action (South Africa) 2001. The pink agenda: Sexual revolution in South Africa and the ruin of the family. Cape Town: Christian Liberty Books.

McNeill, J 1976. The church and the homosexuals. Kansas City, KS: Sheed Andrews and McMeel.

NHKA 2007. Besluitebundel van die $68^{\mathrm{e}}$ Algemene Kerkvergadering van die Nederduitsch Hervormde Kerk van Afrika, Oktober 2007. Pretoria: NHKA Kerkargief (cf htttp//www.nhk.co.za).

Potgieter, J 2006. Permanente homoseksuele verhoudings van liefde en trou. Verbum et Ecclesia 27(1), 174-185.

Potgieter, J 2007. Homoseksualiteit: 'n Skrifgefundeerde perspektief. Vereeniging: CUM Boeke.

Potgieter, J \& Van Huyssteen, F 2002. Homoseksualiteit in perspektief: Hoop en heling uit die Bybel. Wellington: Lux Verbi.

Schaff, P \& Wace, H 1952 (eds). The seven ecumenical councils. Grand Rapids, MI: Eerdmans.

Rouselle, A [1983] 1988. Porneia, tr by F Pheasant. Oxford: Oxford University Press.

Scroggs, R 1983. The New Testament and homosexuality. Philadelphia, PA: Fortress.

Scrijvers, H P 1985. Eine medizinische Erklärung der männlichen Homosexualität aus der Antike. Amsterdam: Uitgeversmaatschappij Holland. (Caelius Aurel, de morbis chronicis, IV, 9.)

Souli, S A [2008] The love life of the ancient Greeks. Sine anno. Available at Gortyn, Crete. Niziza Kaewla, Koropi, Attiki: Michael Toubis Publications. http://www.toubis.gr

Swain, J W 1916. The Hellenic origins of Christian asceticism. PhD thesis. Columbia University, New York.

Vasilakis, A [2008]. Gortyn, tr by J Eiring. Sine anno. Available at Typokreta S.A. Industial area, Iraklio, Crete. V Kouvidis-V. Manouras Editions.

Via, D O 2003. The Bible, the church and homosexuality, in Via, D O \& Gagnon, R A $\mathrm{J}$ (eds), Homosexuality and the Bible, 1-39. Minneapolis, MN: Fortress.

Von Harnack, A 1902. Die Mission und Ausbreitung des Christentums in den ersten drei Jahrhunderten. Leipzig: Hinrichs.

Witte, J 1997. From sacrament to contract: Marriage, religion, and law in the Western tradition. Louisville, KY: Westminster John Knox 